\title{
Britain and the Working Time Regulations
}

Article for 'Politics, January 2001.

\section{Alasdair Blair*, Luchien Karsten** and John Leopold***}

* Research Fellow, Department of European Studies, Loughborough University, UK. From 1 September 2000, Senior Lecturer in International Relations, Coventry University.

** Associate Professor, Faculty of Management and Organisation, University of Groningen, The Netherlands.

*** Associate Dean of Nottingham Business School and Professor of Human Resource Management.

(4450 words) 


\begin{abstract}
It is now over a year since the Working Time Regulations entered force in Britain on 1 October 1998, during a period when the government also introduced the minimum wage. But whereas that piece of legislation appears to have faded away into the background of British industrial relations, the Working Time Regulations continue to remain a central topic, as evidenced by the press coverage given to the recent annual conference of the Trades Union Congress (TUC) in Brighton. ${ }^{\mathrm{i}}$ Based on a survey of British companies and organisations, this article reviews the manner in which the legislation was implemented and examines the scope of coverage. ${ }^{\text {ii }}$ It finds that the failure of the Labour government to consult the social partners - employer and employee representatives - resulted in business being unprepared for the Regulations. The article also notes that the manner in which this legislation was introduced has meant that many of the employees who were working excessive hours are continuing to do so.
\end{abstract}

\title{
Overview
}

The implementation of the Working Time Regulations on 1 October 1998 ended nearly a decade of British opposition to European Union (EU) attempts to regulate working conditions (see appendix 1). And although the Regulations do not implement the whole of the Working Time Directive, Britain has for the first time provisions that include a statutory limit on average weekly hours; a statutory requirement for breaks throughout the day, at the end of the day and every week or fortnight; a general statutory provision for paid annual holidays; controls on the length of night shift working; and the provision of protection for young workers (see appendix 2). The effectiveness of these provisions is, however, diluted by the ability 
for workers to opt-out from the 48-hour maximum working week, which is a singular exception among EU states.

Of other points, the provision for paid holiday entitlement is weakened by the ability for public holidays to be counted as part of any holiday right. These provisions were further limited to three weeks until 23 November 1999, at which stage workers obtained the four-week entitlement established by the Directive. And while the holiday right has not benefited many trade union members (they tend to have at least 4-weeks already), it has helped part-time and agency employees who tended to have few employment rights. This has therefore increased the labour costs incurred by employers which has, for example, taken away the benefit of employing staff on zero hour contracts.ii (This was something that the government did not want to tackle through legislation.)

A resistance by Britain to implement the Directive had been influenced by the then Conservative government regarding working hours (and other social policy matters) as a domestic matter for negotiation between employers, trade unions and employees. Such a stance was influenced by the desire to retain a competitive advantage within the EU through the absence of regulated labour costs. Conservative Ministers consequently challenged the introduction of the EU Working Time Directive in the European Court of Justice in 1996. This course of action proved to be unsuccessful, with the resulting effect that Britain had to prepare for the implementation of the Directive, for which Ministers did so with no sign of impetus or speed. The end product of this state of affairs was that the Labour government that entered office in May 1997 inherited a rather mixed bag of policy developments, including the agreement obtained by the Conservative government that permitted 
employees to choose to work more than 48-hours per week. (Labour was not bound by these decisions.)

\section{A lack of negotiation}

Upon election to office, Labour inherited a policy of implementation that had commenced with the Court of Justice's decision. While this need to implement was not a problem for Labour - they had accepted this policy in opposition - the question of how to implement the Directive did pose a problem. (The Directive provides the ability for different national interpretation.) This was the product of New Labour having to balance the interests of its old trade union comrades and its new business friends who wanted to retain an economically competitive labour force.

A perceived need to reflect these differing pressures did not result in the government embarking in a formal negotiating process involving the social partners. Instead, the Department of Trade and Industry (DTI) sought to obtain business and trade union views by means of a scheduled consultation period from April to July 1998 (when the finalised regulations were placed before Parliament). An absence of round table bargaining that involved all parties mirrored the stance adopted by the previous Conservative administration, and consequently resulted in bilateral rather than multilateral discussions. The end product of this was an absence of hard bargaining between all parties as to what was and was not attainable, and the resulting absence of any real recommendations. ${ }^{\text {iv }}$ A lack of social partner dialogue was a strategic objective by the government to ensure that its viewpoints were not compromised through a formal consultation procedure.

This contrasted with the experience of the minimum wage, where the evidence collection exercise meant that trade unions, employer representatives and employers 
knew that their views were being taken seriously, and they could moreover see that the government wanted to proceed on the basis of consensus. That is not to say that the discussions were easy, because they were often difficult. They did, however, produce a unanimous report by the Low Pay Commission. And while it was subsequently dealt a blow by the government not fully accepting it, this was more the product of tension between the Treasury (Gordon Brown) and the DTI (Margaret Beckett), than about the reality of the policy. In this context, the fundamental point to remember is that whereas employers had argued in late 1997 that anything above $£ 3$ would result in economic chaos, the social partner process resulted in a mutual agreement of $£ 3.60$. Moreover, although there was some initial hesitation concerning the implementation of the minimum wage from 1 April 1999, there has subsequently been very little discussion about this matter.

The Working Time Regulations were, by contrast, devoid of this type of social partner process. Three main factors determined this decision. In the first instance, the Labour government did not intend to make the issue of Working Time a showpiece for its term of government ${ }^{\mathrm{v}}$; it inherited a rather messy policy from the previous Conservative administration and did not set out to dramatically change this situation, despite having the ability to do so. The minimum wage was clearly different, being a policy shaped by Labour and one that they could use as a litmus test of their style of government. Secondly, the government was concerned that any social partner discussion could have resulted in a firmer set of policy guidelines, thereby contradicting the desire to have a flexible interpretation of the Directive. Finally, in the early years of its administration, Labour wanted to present itself as a safe and conservative government, evidenced by budget prudence. An unadventurous interpretation of the Working Time Directive was therefore part of this objective. 
Nevertheless, the reality of the matter is that the Labour government would undoubtedly have achieved a far more agreeable set of guidelines on Working Time if it had entered into some form of social dialogue. ${ }^{\mathrm{vi}}$ This discussion would have produced two principal benefits. The government would have obtained important negotiating experience from the Confederation of British Industry (CBI) and TUC who had participated in social partner dialogue at the EU level, while the social partners could have provided their members with a clearer set of guidelines.

\section{A lack of details}

The problems that surrounded the negotiating process on Working Time (or lack of it) had a direct impact on the manner in which the Regulations were implemented. There were two particular issues associated with this. The first concerned the instructions that the government provided to employers. In this context, it was evident that the lack of a social partner consultation process produced a lower standard of guidelines than could have otherwise been achieved. This point was noted by all correspondents for this research, and was further illustrated by the differing levels of advice offered, as highlighted in tables 1 and 2.

Table 1: Advising on Working Time

\begin{tabular}{|l|c|c|c|c|c|c|}
\hline Advice & $\begin{array}{l}\text { Copy of } \\
\text { Working } \\
\text { Time } \\
\text { Directive }\end{array}$ & Glossary & $\begin{array}{l}\text { Practical } \\
\text { examples }\end{array}$ & $\begin{array}{l}\text { Specimen } \\
\text { agreement }\end{array}$ & $\begin{array}{l}\text { Flow } \\
\text { charts }\end{array}$ & $\begin{array}{l}\text { Page } \\
\text { length }\end{array}$ \\
\hline EEF & No & Yes & Yes & Yes & Yes & 130 \\
\hline MSF & Yes & No & Yes & No & Yes & 79 \\
\hline TUC & No & No & Yes & No & Yes & 55 \\
\hline DTI & No & No & Yes & No & Yes & 74 \\
\hline T\&G & No & No & Yes & No & No & 31 \\
\hline AEEU & No & No & Yes & No & No & 30 \\
\hline USDAW & No & No & Yes & No & No & 24 \\
\hline UNISON & Yes & No & Yes & No & No & 40 \\
\hline
\end{tabular}


An examination of these documents shows that the official DTI guideline was not the most comprehensive survey, a point emphasised by the Secretary of State for Trade and Industry, Stephen Byers, ordering a rewrite of the DTI's guide to the working time regulations in March 1999. ${ }^{\text {vii }}$ This was in response to complaints from business about mistakes, omissions and misleading entries. ${ }^{\text {vii }}$ By that stage, the initial version had already been changed, with the second version being identified by the appearance of the word 'workright' on its cover. Among the inaccuracies it corrected, were the wrong formula for calculating average hours of night work, two different formulae for working out compliance with the 48-hour week and an arithmetic error in an example of night work calculation.

Other disparities between the advice offered by the DTI and professional organisations included definitions regarding on-call workers that had to sleep on site, the question of unmeasured working time and the issue of travelling time (see table 2). In these three areas the DTI guidance was unclear and left a great deal of scope for interpretation, resulting in some employers going against government advice. This included the National Health Service Executive, which stressed that 'those workers who are required by their employer to be at their place of work and sleepingin, will be considered to be working as they are at their employer's disposal and carrying out their duties' (NHS, 1998, p.2, emphasis added). This clearly went against the DTI position that 'if a worker is required to be at the place of work 'on call', but was sleeping though available to work if necessary, a worker would not be working and so the time spent asleep would not count as working time' (DTI, 1998, p.16, emphasis added).

Of other points, the DTI position on travelling time was equally blurred as it provided no guidelines on whether time spent sleeping on a plane was working time 
or not, which resulted in many major companies concluding that travelling time was working time. ${ }^{\mathrm{ix}}$ This was based on the assumption that although employees may not have been working while they were travelling, they were nevertheless in the course of their employment and that if they did not classify this as working time then they would be exposing themselves from the point of view of personal injury law. ${ }^{\mathrm{x}}$ In both these cases the DTI had therefore favoured a minimalist position that did not set concrete objectives. In this context, the degree of implementation would be established at company level, with the intention of making the impact on industry as minimal as possible. This strategy did, of course, contradict the objective of the Directive to establish a uniform standard.

Table 2: Classifications of Working Time

\begin{tabular}{|c|c|c|c|}
\hline Advice & $\begin{array}{l}\text { On Call and sleeping } \\
\text { on site }\end{array}$ & $\begin{array}{l}\text { Unmeasured } \\
\text { working time }\end{array}$ & ling time \\
\hline$\overline{\text { EEF }}$ & $\begin{array}{l}\text { No clear advice. } \\
\text { Suggested workers } \\
\text { who are on call and on } \\
\text { site could be classified } \\
\text { as working time. }\end{array}$ & $\begin{array}{l}\text { Only those managing } \\
\text { executives } \\
\text { work is not measured } \\
\text { or predetermined are } \\
\text { excluded. }\end{array}$ & $\begin{array}{l}\text { Travelling to work is not } \\
\text { working time, but time } \\
\text { spent travelling to visit a } \\
\text { client is working time, } \\
\text { as is travelling abroad. }\end{array}$ \\
\hline MSF & $\begin{array}{l}\text { Should be considered } \\
\text { as working time. }\end{array}$ & $\begin{array}{l}\text { Stresses that it would } \\
\text { be unusual for more } \\
\text { than } 1 \text { or } 2 \text { people in } \\
\text { a business that had } \\
\text { autonomous decision- } \\
\text { making powers. }\end{array}$ & $\begin{array}{l}\text { Working time is when a } \\
\text { worker is expected to } \\
\text { engage in activity on } \\
\text { behalf of the employer, } \\
\text { such as travel to a } \\
\text { distant workplace. }\end{array}$ \\
\hline TUC & $\begin{array}{l}\text { Should be established } \\
\text { by collective or } \\
\text { relevant agreements. }\end{array}$ & $\begin{array}{l}\text { Most managers are } \\
\text { outwith this category, } \\
\text { having a degree of } \\
\text { measured time. }\end{array}$ & $\begin{array}{l}\text { Should be established by } \\
\text { collective or relevant } \\
\text { agreements. }\end{array}$ \\
\hline$\overline{\text { DTI }}$ & $\begin{array}{l}\text { If a worker is on call, } \\
\text { but was sleeping } \\
\text { though available to } \\
\text { work, then this should } \\
\text { not be counted as } \\
\text { working time. }\end{array}$ & $\begin{array}{l}\text { Vague description } \\
\text { that includes workers } \\
\text { with managerial } \\
\text { responsibility, } \\
\text { suggesting that they } \\
\text { are excluded. }\end{array}$ & $\begin{array}{l}\text { Travel to and from work } \\
\text { not counted as working } \\
\text { time, though working } \\
\text { abroad does count. No } \\
\text { advice on other travel, } \\
\text { such as from workplace } \\
\text { to workplace. }\end{array}$ \\
\hline T\&G & $\begin{array}{l}\text { Little advice. States } \\
\text { that negotiators should } \\
\text { obtain a definition that } \\
\text { suits their own needs. }\end{array}$ & $\begin{array}{l}\text { Unclear advice. } \\
\text { States that managers } \\
\text { are covered, but no } \\
\text { concrete information. }\end{array}$ & $\begin{array}{l}\text { Little advice. States that } \\
\text { negotiators should } \\
\text { obtain a definition that } \\
\text { suits their own needs. }\end{array}$ \\
\hline
\end{tabular}




\begin{tabular}{|l|l|l|l|}
\hline AEEU & No advice. & $\begin{array}{l}\text { No advice, but } \\
\text { suggested that this } \\
\text { only apply to } \\
\text { managing executives. }\end{array}$ & No advice. \\
\hline USDAW & No advice. & Senior executives. & No advice. \\
\hline UNISON & No advice. & $\begin{array}{l}\text { Most managers do } \\
\text { not have control over } \\
\text { working hours. }\end{array}$ & $\begin{array}{l}\text { Should be covered by } \\
\text { Regulations. } \\
\text { examples provided. }\end{array}$ \\
\hline
\end{tabular}

The second problem concerned the dearth of information that was available to business and trade union representatives, who spent much of July and August 1998 speculating as to what the specific detail of the Regulations would be. This was because they had not been privy to the same level of information as would have been the case had there been a social partner process. The resulting effect of this was to leave many organisations unprepared for the implementation of the Regulations, a difficulty that was further accentuated because they were only provided with the government's guidelines in September, just weeks before the Regulations took effect. $^{\mathrm{xi}}$ This situation obviously impacted on the quality of advice that was provided, as well as its very timing. As a TUC official commented, 'it would have been much easier to manage implementation if the Regulations had been part of a negotiated process, which would then have reduced the number of complaints from employers'. ${ }^{\text {ii }}$ This was a view equally held by the CBI. ${ }^{\text {xiii }}$

This state of affairs prompted many employers to make individual decisions regarding who was or was not covered by the Regulations. For most, the crucial issue was to establish who would not be covered. In the case of the 48-hour limit, some companies took the unilateral decision to exempt whole tiers of upper management from this provision as well as insisting that new graduate recruits sign opt-outs. And although this clearly flouts the spirit of the Regulations, which provides the example of senior executives, many businesses considered it to be an acceptable practice. (Many of these employees are, of course, not union members.). 


\section{Scope and coverage}

So what has been the effect of the Regulations on British employment practices? First of all, the 48-hour week provision has not had a significant impact in changing working practices. All of the companies that were contacted for this research had contracted weekly hours of 40-hours or less, while they also noted a movement away from the use of overtime. And when employees did work in excess of 48-hours, they did so for only a short period of time, such as the Christmas sales. At the other end of the spectrum, the 48-hour week has had little impact in curtailing the number of hours worked by managers. The simple reason for this is that many white-collar management employees have chosen to opt-out of the 48-hour limit, or do not bother with the Regulations.

This problem is likely to be exacerbated by the recent amendments to the Regulations that were tabled by the government on $27^{\text {th }}$ July 1999 , including an extension to the definition of unmeasured working time. ${ }^{\text {xiv }}$ The intention here is to allow those workers who have an element of their working time that is predetermined, such as by means of contract, to work longer hours if they choose to do so. ${ }^{\mathrm{xv}}$ The significance of these developments is that they show little evidence of any move towards a negotiated reduction in working hours. This therefore leaves open the issue of how government, employers and trade unions will respond when the European Commission likely puts a stop to this procedure when it is reviewed in 2003. Some unions also appear to be reluctant to tackle this issue because it would lead to reductions in pay. ${ }^{\mathrm{xvi}}$

\section{Conclusion}


The above information demonstrates that the Working Time Regulations have had a mixed impact in Britain, while they have not curbed the major problem of managerial employees working excessive hours. Britain is, of course, not alone in having this problem, with weekly hours being longer in America (ILO, 1999), though Britain has a long-hour culture in EU terms. ${ }^{\text {xvii }}$ There is moreover no evidence to suggest that any effort is being made to develop a negotiated reduction in working hours.

The reality of this situation can be traced back to the manner in which the Regulations were implemented, with their being no social partner involvement. This could have been different, as the government had plenty of time to think about involving the unions and employers. We have to remind ourselves that the process of consultation did not commence until April 1998, one month short of a year after Labour took office. The second point to bear in mind is that a negotiated reduction in hours, rather than creating a blanket provision, would have avoided some of the bureaucracy that companies have had to face in recording hours of work, as it would initially have permitted a higher number of weekly hours. The third point is that the government was aware that Ireland adopted a negotiated reduction in working hours and such a path was therefore not a new one (Ireland, 1997). ${ }^{\text {xiii }}$ Such changes may have resulted in a different outcome, with the likelihood of reducing the continued effort spent by Ministers and officials on this subject.

That is not to say that the Regulations are not important. They are. For the first time in recent history a British government has provided workers with important employment rights, many of whom had no or only few existing entitlements. It is unlikely that these new benefits will, however, benefit all, as many workers continue to be employed in sweatshops on the fringes of the economy, while the government has only provided few resources to enforce the Regulations. There are, in fact, fewer 
than 10 Health and Safety Executive enforcing officers. But, the point to remember is that although the government might not be able to examine the working practices of all the sweatshop operators, it is able to tackle the conditions of work faced by those in the mainstream of economy. 


\section{Appendix 1: \\ Working Time Chronology}

Dec.1989: Social Charter signed by EC Member States (except UK) at Strasbourg European Council.

Sept. 1990: Commission submitted its proposal for a Draft Directive concerning certain aspects of the Organisation of Working Time.

June 1992: UK obtained concessions at a meeting of the Social Affairs Council on 24 June, including the ability to work for more than 48-hours per week.

June 1993: Council reached agreement on a common position on the draft Working Time Directive on 1 June. UK announced its intention to challenge the Directive's legal base at the meeting.

Nov.1993: Commission resubmitted its proposal to the Council on 23 November, where it was adopted by means of QMV (UK abstained).

March 1994: UK made its application to the European Court of Justice for the annulment of the Directive.

March 1996: Advocate General of the European Court of Justice gave his opinion on 12 March, which went against the UK.

Nov. 1996: European Court of Justice confirmed its opinion on 12 November 1996.

Nov. 1996: UK accepted that the Working Time Directive would have to be implemented within Britain.

Dec. 1996: UK government issued a consultative document on 6 December for the implementation of the Working Time Directive.

June 1997: UK Labour government accepted the Social Chapter at Amsterdam European Council.

April 1998: Labour government issued draft implementing Regulations for consultation on the Working Time Directive.

July 1998: Working Time Regulations were laid before the UK Parliament.

Oct. 1998: Working Time Regulations entered force in the UK. 


\section{Appendix 2: \\ Key provisions of Working Time Regulations}

1. Maximum weekly working time of 48 hours (including overtime) averaged over a 17-week reference period [Regulation 4]. The reference period can be varied by collective agreement to a duration not exceeding 52 weeks. Individuals can optout of the 48-hour limit [Regulation 5].

2. A minimum of two uninterrupted rest periods of 24 hours in every 14 days, or one uninterrupted 48-hour rest period in every 14 days. In addition, every worker must have a daily rest period of 11 hours. The weekly rest period for young workers must be 48 hours (rather than 24 for an adult). [Regulation 11].

3. A rest break for 20 minutes for workers whose working day is longer than 6 hours. An uninterrupted daily rest period of 11 hours, and a weekly rest period of at least 24 hours in seven days.

4. A minimum period of leave of 3 weeks per year (after 13 weeks' service), rising to 4 weeks by 23 November 1999 . Part-time workers have to receive pro-rata entitlements.

5. Night workers cannot be required to work more than 8 hours per night (on average). This is a maximum limit if the work involves special hazards or mental strain. 


\section{References}

AEEF (1998) A Practical Guide to the Working Time Regulations, London: Amalgamated Engineering and Electrical Union.

Council (1993) 93/104 Council Directive/EC of 23 November 1993 concerning certain aspects of the organisation of working time.

DTI (1998) Regulatory Guidance: Working Time Conditions, London: Department of Trade and Industry.

EEF (1998) Implementing the Working Time Regulations: A Practical Guide, London: Engineering Employers' Federation.

European Court of Justice (1996) Judgement of the Court, 12 November, in Case C84/94, United Kingdom of Great Britain and Northern Ireland $v$ Council of the European Union.

ILO (1999) Key Indicators of the Labour Market 1999, London: International Labour Office.

Ireland (1997) Organisation of Working Time Act, Dublin: Department of Enterprise, Trade and Employment.

MSF (1998) Working Time: MSF Guidance, London: Manufacturing, Science and Finance Union.

NHS (1998) Working Time Regulations: Implementation in the NHS, Leeds, NHS Executive Health Service Circular, HSC 1998/204.

T\&G (1998) The Working Time Regulations: A T\&G Guide, London: Transport and General Workers Union.

TUC (1998) A TUC Guide: Working Time Regulations 1998, London: Trades Union Congress.

UNISON (1998) Working Time Regulations: A Negotiators Guide, London: UNISON

UK (1998) Statutory Instrument 1998 No.1833: The Working Time Regulations 1998, London: HMSO.

USDAW (1998) The Working Time Directive: where do we go from here?, Manchester: Union of Shop, Distributive and Allied Workers. 


\section{Notes}

1. Financial Times, 14 September 1999, p.10.

2. Interviews were conducted between March and August 1999 with the following companies and organis ations: Abbey National Bank; Boots Company; Advisory, Conciliation and Arbitration Service (ACAS); British Nursing Association (BNA); Confederation of British Industry (CBI); Group 4 Security; Ikea; J. Sains bury; Marks and Spencer; NottinghamUniversity Hospital NHS Trust; Novotel; Powergen; Raleigh Cycles; Trades Union Congress (TUC); Van den Bergh Foods.

3. Under zero hour contracts employees can be either asked to be available for work, but without the guarantee of employment, or where an employee is informed that work will be available on a specific day or days.

4. Interviews: CBI and TUC, 22 June 1999.

5. Interview: CBI, 22 June 1999.

6. See "Unions and employers should 'reach consensus",, Financial Times, 13 September 1999, p.14.

7. Financial Times, 5 March 1999, p.1.

8. People Management, 8 April 1999.

9. Authors interviews.

10. Authors interviews.

11. Financial Times, 28 September 1999.

12. Interview: TUC, 22 June 1999.

13. Interview: CBI, 22 June 1999.

14. Daily Telegraph, 26 August 1999, p.9 and Times, 16 September 1999, p.30.

15. See 'One in three will lose work hours protection', Daily Telegraph, 26 August 1999, p.9.

16. Authors interview, 7 April 1999.

17. Financial Times, 25 August 1999, p.8.

18. This provides employees with the ability to work up to 60-hours per week from 1 March 1998 to 28 February 1999 and up to 55-hours per week from 1 March 1999 to 29 February 2000, after which the 48-hour week takes affect for all covered employees on 1 March 2000. 